\title{
Silage quality of six sorghum cultivars for sheep
}

\author{
Brena Santos Oliveira ${ }^{(1)}$, Luiz Gustavo Ribeiro Pereira ${ }^{(2)}$, José Augusto Gomes Azevêdo(1), \\ José Avelino Santos Rodrigues(3), Frederico Osório Velasco(4), André Luiz Alves Neves ${ }^{(2)}$, \\ Rogério Martins Maurício( ${ }^{(4)}$, Rui da Silva Verneque ${ }^{(2)}$ and Rafael Dantas dos Santos ${ }^{(5)}$
}

\begin{abstract}
(1)Universidade Estadual de Santa Cruz, Campus Soane Nazaré de Andrade, Rodovia Jorge Amado, Km 16, Salobrinho, CEP 45662-900 Ilhéus, BA, Brazil. E-mail: brenabso@gmail.com, augustog@uesc.br (2)Embrapa Gado de Leite, Rua Eugênio do Nascimento, no 610, Dom Bosco, CEP 36038-330 Juiz de Fora, MG, Brazil. E-mail: luiz.gustavo@embrapa.br, andre.neves@embrapa.br, rui.verneque@embrapa.br ${ }^{(3)}$ Embrapa Milho e Sorgo, Rodovia MG-424, Km 45, Zona Rural, CEP 35701-970 Sete Lagoas, MG, Brazil. E-mail: avelino.rodrigues@embrapa.br (4)Universidade Federal de São João Del Rey, Campus Dom Bosco, Praça Frei Orlando, no 170, Centro, CEP $36307-352$ São João Del Rei, MG, Brazil. E-mail: fredericovelasco@gmail.com, rogeriomauricio@ufsj.edu.br (5)Embrapa Semiárido, Rodovia BR-428, Km 152, s/no, Zona Rural, CEP 56302-970 Petrolina, PE, Brazil. E-mail: rafael.dantas@embrapa.br
\end{abstract}

Abstract - The objective of this work was to evaluate the silage quality, fermentation profile, intake, and digestibility of six sorghum cultivars for sheep feeding. 'SF 15', 'IPA 2502', 'BRS 655', 'BR 601', 'BRS 506', and 'Sudão' were cultivated in randomized complete block designs with five replicates, harvested, and ensiled when plants reached the soft-dough grain stage. Silage quality was determined in laboratory silos. Intake and apparent digestibility were determined during 22 days, using 24 Santa Inês lambs $(35.5 \pm 2.21 \mathrm{~kg})$ randomly distributed in the treatments. Silage from 'IPA 2502' had the lowest contents of dry matter, neutral detergent fiber, and acid detergent fiber; the highest nonfibrous carbohydrate and total digestible nutrient contents; and the greatest dry matter degradability. Silages from 'BR 601' and 'BRS 506' showed the highest values of crude protein, whereas those of 'SF 15' and 'Sudão' had the highest levels of fibrous fractions. Lambs fed silage from 'IPA 2502' consumed more dry matter and nonfibrous carbohydrates, and their crude protein digestibility was also greater than that from the consumption of other cultivar silages. 'IPA 2502' stands out for its nutritional characteristics, which resulted in better animal performance.

Index terms: Sorghum, digestibility, fermentation profile, nutritional value, ruminants, semiarid conditions.

\section{Qualidade das silagens de seis cultivares de sorgo para ovinos}

Resumo - O objetivo deste trabalho foi avaliar a qualidade da silagem, o perfil de fermentação, o consumo e a digestibilidade de seis cultivares de sorgo para alimentação de ovinos. 'SF 15', 'IPA 2502', 'BRS 655', 'BR 601', 'BRS 506' e 'Sudão' foram cultivadas em delineamento de blocos ao acaso com cinco repetições, colhidos e ensilados quando as plantas atingiram o estádio pastoso da maturidade dos grãos. A qualidade da silagem foi determinada em silos de laboratório. O consumo e a digestibilidade aparente foram determinados durante 22 dias, tendo-se utilizado 24 cordeiros da raça Santa Inês $(35,5 \pm 2,21 \mathrm{~kg})$ distribuídos aleatoriamente entre os tratamentos. A silagem de 'IPA 2502' apresentou os menores teores de matéria seca, fibra em detergente neutro e fibra em detergente ácido; os maiores teores de carboidratos não fibrosos e nutrientes digestíveis totais; e a maior degradabilidade da matéria seca. As silagens oriundas de 'BR 601' e 'BRS 506' apresentaram os maiores valores de proteína bruta, enquanto aquelas de 'SF 15' e 'Sudão', os maiores teores das frações fibrosas. Os cordeiros alimentados com a silagem de 'IPA 2502' consumiram mais matéria seca e carboidratos não fibrosos, e a sua digestibilidade de proteína bruta também foi maior do que a oriunda do consumo da silagem de outras cultivares. 'IPA 2502' destaca-se por suas características nutricionais, as quais resultaram em melhor desempenho animal.

Termos para indexação: Sorghum, digestibilidade, perfil de fermentação, valor nutricional, ruminantes, condições semiáridas.

\section{Introduction}

The rising world population, economic growth, and greater purchasing power in developing countries affect the dynamics of food production and water use (Wheeler \& Von Braun, 2013). In this scenario, the use of forages resistant to these variations becomes an important strategy to ensure the correct levels of supplementation to ruminants throughout the year.

Sorghum [Sorghum bicolor (L.) Moench] is well adapted to sudden climatic variations, showing high concentrations of soluble carbohydrates either under 
excessive rains or periods of drought. In addition, sorghum is one of the main sources of feed for ruminants in semiarid regions in the tropics (Silva et al., 2012; Moura et al., 2016). To ensure enough forage production to supplement the animal diet throughout the year, it is necessary to develop high-yielding cultivars adapted to target environments.

Embrapa and Instituto Agronômico de Pernambuco (IPA) have been working on the development of new sorghum cultivars with high productivity and resistance to environmental inclemencies, and launched 'IPA 2502', 'BRS 655', 'BR 601', 'BRS 506', and 'BRS 610' (Neves et al., 2015).

Although there are studies on the feasibility of these materials in semiarid conditions, few evaluations were made on the feasibility of their use for sheep feeding. On this subject, Neves et al. (2015) observed that sheep fed silages from 'BRS 655', 'BR 601', and 'BRS 506', showed DM intake and digestibility similar to those reported in studies on forage sorghum and BMR (brown midrib) forage sorghum cultivars under temperate conditions (Miron et al., 2007; Ledgerwood et al., 2009).

Considering the adaptation traits of these cultivars to soil and climatic conditions of semiarid regions, and the productive potential previously reported in other studies (Santos et al., 2013; Neves et al., 2014, 2015; Costa et al., 2016), the evaluation of their nutritional value is indispensable. In the same way as the evaluation of forage at a field scale and of the agronomic traits are important, the forage nutritional value and the animal digestive behavior are essential for a complete analysis of a potential new cultivar.

The objective of this work was to evaluate the silage quality, fermentation profile, intake, and digestibility of six sorghum cultivars for sheep feeding.

\section{Materials and Methods}

The experiment was carried out from June to September 2011, at the experimental field of Embrapa Semiárido, in the municipality of Nossa Senhora da Glória, in the state of Sergipe, Brazil $\left(10^{\circ} 13^{\prime} 06^{\prime \prime S}\right.$, $37^{\circ} 25^{\prime} 13^{\prime \prime} \mathrm{W}$, at $291 \mathrm{~m}$ altitude). Six sorghum cultivars developed by the breeding programs of Embrapa and Instituto Agronômico de Pernambuco (IPA) were used, identified by the following names or codes: 'SF 15' and 'IPA 2502' [S. bicolor x S. sudanense (Piper) Stapf];
'Sudão' [Sorghum sudanense (Piper) Stapf]; 'BRS 655', 'BRS 601', and 'BRS 506' (S. bicolor) (Table 1).

A randomized complete block design with six treatments (sorghum cultivars) and five replicates was used. Two trials were performed: evaluation of silage quality using minisilos and the in vitro gas production technique; and evaluation of intake and apparent digestibility in lambs.

Sowing was performed manually on May 31, 2011, using 20 seed per linear meter. At sowing, $150 \mathrm{~kg} \mathrm{ha}^{-1}$ ammonium sulfate $+450 \mathrm{~kg} \mathrm{ha}^{-1}$ triple superphosphate $+100 \mathrm{~kg} \mathrm{ha}^{-1}$ potassium chloride were used. For top dressing, two fertilizations were performed: the first after 30 days, and the second after 60 days of seedling emergence, using $150 \mathrm{~kg} \mathrm{ha}^{-1}$ ammonium sulfate.

The plots were constituted by five rows of $10 \mathrm{~m}$ long, spaced $0.7 \mathrm{~m}$ apart. After thinning at 20 days of emergence, plant density was approximately 20 plants per linear meter. The useful plot size was made up of the two central rows, excluding $0.5 \mathrm{~m}$ from the extremities, totaling $6.3 \mathrm{~m}^{2}$.

Plants were manually cut at $10 \mathrm{~cm}$ above the ground level, when they reached the soft-dough stage.

Experimental silos of PVC pipes (polyvinyl chloride) with $10 \mathrm{~cm}$ diameter and $50 \mathrm{~cm}$ length, with 4.0 to $4.5 \mathrm{~kg}$ capacity, were used to obtain the silages. The material was manually compacted.

The silos were opened after 180 days and silage was homogenized for $\mathrm{pH}$ determination (Helrich, 1990). Analyses of lactic, acetic, propionic, and butyric organic acids were performed according to Adams et al. (1984). Ammoniacal nitrogen content in relation to total nitrogen $\left(\mathrm{N}-\mathrm{NH}_{3} / \mathrm{TN}\right)$ was measured after distillation with magnesium oxide and calcium chloride (Helrich, 1990). A portion of silage sampled from each silo was pre-dried in forced-ventilation oven at $55^{\circ} \mathrm{C}$ for 72 hours, for further analysis of dry matter (DM), nitrogen compounds $(\mathrm{N})$, mineral matter $(\mathrm{MM})$, ether extract (EE) and acid detergent fiber (ADF) (Helrich, 1990). The determination of neutral detergent fiber (NDF) was performed according to Mertens (2002), and the obtained values were corrected for ash and protein. Lignin was obtained according to Van Soest \& Robertson (1985).

The fractions that constitute the total carbohydrates (TC) were estimated by subtracting the values of EE and $\mathrm{CP}$ contained in organic matter. The nonfibrous carbohydrates (NFC) were estimated by subtracting 
the EE, CP, and NDF contents contained in organic matter. Total digestible nutrients were estimated from the chemical composition of the silages (Detman et al., 2007). A semiautomated in vitro gas production technique was performed as described by Maurício et al. (2003). The culture medium used was composed of buffer solutions, and macro- and microminerals (Menke \& Steingass, 1988). The ruminal inoculum was obtained from two male bovines fistulated in the rumen, which were grazing on Urochloa decumbens (Syn. Brachiaria decumbens), supplemented with $2.0 \mathrm{~kg}$ per day concentrate with $20 \%$ CP. Ruminal fluid collection was performed in the morning, in a single collection, before the supply of concentrate. The material was conditioned into a preheated thermo bottle at $39^{\circ} \mathrm{C}$ which was immediately taken to the laboratory for the incubation procedure (Theodorou et al., 1994). Glass vials $(190 \mathrm{~mL})$ were used and sealed with rubber stoppers, and subsequently kept at $39^{\circ} \mathrm{C}$. The gas pressure and the dry matter disappearance (DDM) were evaluated at $1,2,3,4,6,8,10,12,18,24,30,48$, $54,60,72,96,120,144,264$ hours. The results were blank-corrected (bottle containing ruminal fluid with culture medium, without the sample), and compared to the standard ('Tifton 85' hay) for validation of the methodological procedure. The regression equation used for the conversion of pressure $(\mathrm{P})$ to volume was: $\mathrm{V}(\mathrm{mL})=0.04755+1.9754 \mathrm{P}+0.01407 \mathrm{P}^{2}\left(\mathrm{R}^{2}=0.99\right)$, in which $\mathrm{V}$ is the the volume of gases produced, and $\mathrm{P}$ is the pressure in psi.

The variables related to the in vitro ruminal fermentation kinetics were investigated by the bicompartmental model (Schofield et al., 1994) as follows: $\mathrm{V}=\mathrm{FV}_{\mathrm{NFC}} /\left[1+\exp \left(2-4 \times \mathrm{kd}_{\mathrm{NFC}} \times(\mathrm{T}-\mathrm{L})\right)\right]+$ $\mathrm{FV}_{\mathrm{FC}} /\left[1+\exp \left(2-4 \times \mathrm{kd}_{\mathrm{FC}} \times(\mathrm{T}-\mathrm{L})\right)\right]$, in which: $\mathrm{FV}_{\mathrm{NFC}}$ represents the maximum volume of gases from NFC; $\mathrm{kd}_{\mathrm{NFC}}$ is the degradation rate $\left(\mathrm{h}^{-1}\right)$ of this same NFC fraction; $\mathrm{FV}_{\mathrm{FC}}$ is the maximum gas volume of the $\mathrm{FC}$ fraction; $\mathrm{kd}_{\mathrm{FC}}$ is the degradation rate $\left(\mathrm{h}^{-1}\right)$ of $\mathrm{FC}$; and $\mathrm{T}$ and $\mathrm{L}$ are the incubation times (h) and latency (h), respectively.

Effective degradability of dry matter (EDDM) was calculated considering the rates of passage of rumen solids of $2 \% \mathrm{~h}^{-1}$ (low), $5 \% \mathrm{~h}^{-1}$ (normal), and $8 \% \mathrm{~h}^{-1}$ (high). The degradability parameters of DM and NDF were obtained by the models $\mathrm{Y}=\mathrm{a}+\mathrm{b} \times\left(1-\mathrm{e}^{\mathrm{ct}}\right)$ and $\mathrm{Y}=\mathrm{b}^{\prime}-\mathrm{B} \times \exp \left({ }^{-\mathrm{ct}}\right)$. In the model $\mathrm{Y}=\mathrm{a}+\mathrm{b} \times\left(1-\mathrm{e}^{\mathrm{ct}}\right)$, variables are described as: Y, DM disappearance (\%) at time t; a, soluble fraction (\%); b, potentially degradable insoluble fraction (\%); c, degradation rate $\left(\mathrm{h}^{-1}\right)$ of the fraction $b ; t$, incubation time (h). In the model $\mathrm{Y}=\mathrm{b}^{\prime}-\mathrm{B} \times \exp \mathrm{(}^{-\mathrm{ct})}$, the variables are described as: $\mathrm{Y}$, NDF disappearance (\%) at time $t$; $b$ ' is equal to $B$, the potentially degradable insoluble fraction, which will be degradable as a function of time, at a degradation rate c; exp, basis of the neperian logarithms; c, degradation rate of the fraction $B$ per unit of time $\left(h^{-1}\right)$; and $t$, the incubation time. The nondegradable NDF fraction (I) was obtained by the formula $I=100-b$ '.

The apparent digestibility of nutrients from the six sorghum cultivars ensiled in plastic containers was measured during 22 days, using 24 Santa Ines lambs $(35.5 \pm 2.21 \mathrm{~kg})$ randomly distributed into six treatments. The first 17 days were used to adapt the animals to the experimental diet, in individual metabolic cages $\left(2.3 \mathrm{~m}^{2}\right)$ equipped with a feeder, drinker, and feces and urine collectors with a polyethylene sieve to separate feces from urine. Then, the intake and excretion of each lamb were measured individually. Lambs were fed twice a day, at 7:30 and 16:30 h, allowing leftovers of $10-15 \%$ of the total feed supplied. Water and mineral salt were offered ad libitum. Intake and apparent digestibility of nutrients data were obtained during a five-day collection period. Samples of feed,

Table 1. Agronomic characteristics of the evaluated sorghum (Sorghum bicolor and S. sudanense) cultivars ${ }^{(1)}$.

\begin{tabular}{|c|c|c|c|c|c|c|}
\hline Cultivar & Type & $\begin{array}{l}\text { Mean height } \\
\text { (m) }\end{array}$ & $\begin{array}{c}\text { Total } \\
\text { cycle }^{(1)}\end{array}$ & $\begin{array}{l}\text { Productivity } \\
\left(\mathrm{Mg} \mathrm{ha}^{-1}\right)\end{array}$ & $\begin{array}{l}\text { Type of } \\
\text { panicle }\end{array}$ & $\begin{array}{l}\text { Grain } \\
\text { color }\end{array}$ \\
\hline SF 15 (IPA $7301218 \times$ IPA 7301158) & Variety & 3.0 & 95 & 55 & Semi-open & Light brown \\
\hline IPA $8602502($ IPA $7301011 \times$ F 71464) & Hybrid & 1.9 & 80 & 40 & Semi-open & Light brown \\
\hline Sudão & Variety & 2.8 & 60 & 40 & Open & White \\
\hline BRS 655 (CMSXS 222A × CMSXS 235R) & Hybrid & 2.5 & 90 & 50 & Semi-open & Brown \\
\hline BRS $601($ CMS $143 \times$ CMS 2011) & Hybrid & 3.0 & 100 & 50 & Semi-open & Red \\
\hline BRS $506(\mathrm{CMSS} 13509 \times$ CMSS14511) & Variety & 3.0 & 120 & 55 & Semi-open & White \\
\hline
\end{tabular}

(1)Plant cycle, in days, for silage at the soft dough stage. 
leftovers, and feces were collected daily and mixed to form a subsample (400 $\mathrm{g}$ feces, $400 \mathrm{~g}$ leftovers, and $400 \mathrm{~g}$ of feed offered per animal). Subsequently, the subsample was stored in a cold room at $-20^{\circ} \mathrm{C}$ and subjected to bromatological analyses similar to that of the silage quality test.

The trial using sheep was conducted according to the guidelines of the National Council for the Control of Animal Experimentation.

Analyses of variance were performed to evaluate silage quality. At the trial on kinetics of ruminal fermentation in vitro, the gas production and degradability data were analyzed by nonlinear regression, using the Gauss-Newton method with the aid of the SAS software (SAS Institute Inc., Cary, $\mathrm{NC}$, USA). In both trials, the significant variables had their means compared by the Scott-Knott's test, at 5\% probability. For the analysis of intake and digestibility, data were evaluated by Fisher's test, at 5\% probability.

\section{Results and Discussion}

The dry matter contents of silages ranged from 262.9 to $352.4 \mathrm{~g} \mathrm{~kg}^{-1}$ (Table 2), and sorghum 'BRS 506', 'BRS 601', and 'Sudão' were superior to the other treatments. The organic matter values were higher for 'IPA 2502', 'BRS 506', 'Sudão', and 'SF 15', and lower for 'BRS 655'.

The silages from 'BRS 601' and 'BRS 506' had the highest concentrations for crude protein concentration.
The highest values of neutral detergent-insoluble nitrogen (NDIN) and acid detergent-insoluble nitrogen (ADIN) were observed for silages from 'Sudão' and 'BRS 655'. Sorghum 'IPA 2502' had the highest NFC value (433.9 $\left.\mathrm{g} \mathrm{kg}^{-1} \mathrm{DM}\right)$. The neutral detergent fiber, corrected for ash and protein (NDFap), and acid detergent fiber, corrected for ash and protein (ADFap), were higher for silages from 'SF 15' and 'Sudão', and lower for 'IPA 2502' which also showed the lowest lignin and the highest TDN values. However, no significant differences were found for in vitro dry matter digestibility values after 48 hours $\left(607.0 \mathrm{~g} \mathrm{~kg}^{-1}\right.$ mean value of).

Low-DM values may favor the growth of undesirable microorganisms such as clostridia, the major group of anaerobic bacteria that are detrimental to silage quality (Brüning et al., 2018). Amongst the silages evaluated, only that from 'IPA 2502' hybrid had values below the recommended ones. This genotype shows a higher precocity thant other ones and a succulent stem, but its lower proportion of panicle may have interfered with the dry matter content of this material (Neves et al., 2015). Panicle is the fraction of the plant of highest dry matter content, directly influencing the total dry matter content of silage. However, the dry matter content is not the only aspect that affects silage quality. According to McDonald et al. (1991), if the forage has sufficient amounts of soluble carbohydrates, dry matter contents of $20 \%$ are sufficient to guarantee an adequate fermentation and conservation of the material.

Table 2. Dry matter (DM) content and chemical composition of silages from six sorghum (Sorghum bicolor and S. sudanense) cultivars $^{(1)}$

\begin{tabular}{lcccccccc}
\hline Variable & SF 15 & IPA 2502 & Sudão & BRS 655 & BRS 601 & BRS 506 & Mean & CV (\%) \\
\hline DM $\left(\mathrm{g} \mathrm{kg}^{-1}\right)$ & $289.5 \mathrm{c}$ & $262.9 \mathrm{~d}$ & $352.1 \mathrm{a}$ & $336.1 \mathrm{~b}$ & $343.4 \mathrm{a}$ & $352.4 \mathrm{a}$ & 324.6 \\
\hline & & \multicolumn{7}{c}{ Chemical composition $\left(\mathrm{g} \mathrm{kg}^{-1} \mathrm{DM}\right)$} \\
Organic matter (OM) & $952.8 \mathrm{a}$ & $948.6 \mathrm{a}$ & $952.9 \mathrm{a}$ & $927.1 \mathrm{c}$ & $947.5 \mathrm{~b}$ & $948.6 \mathrm{a}$ & 943.9 & 0.7 \\
Crude protein (CP) & $20.2 \mathrm{~d}$ & $35.7 \mathrm{c}$ & $25.9 \mathrm{~d}$ & $65.3 \mathrm{~b}$ & $93.2 \mathrm{a}$ & $86.3 \mathrm{a}$ & 52.0 & 17.3 \\
Ether extract (EE) & $20.8 \mathrm{~b}$ & $32.1 \mathrm{a}$ & $25.5 \mathrm{~b}$ & $27.5 \mathrm{a}$ & $32.8 \mathrm{a}$ & $28.8 \mathrm{a}$ & 27.1 & 20.6 \\
NDIN/TN & $14.0 \mathrm{~b}$ & $8.4 \mathrm{c}$ & $15.3 \mathrm{a}$ & $15.5 \mathrm{a}$ & $12.2 \mathrm{~b}$ & $10.1 \mathrm{~b}$ & 12.7 & 13.3 \\
ADIN/TN & $13.7 \mathrm{a}$ & $7.9 \mathrm{c}$ & $16.7 \mathrm{a}$ & $14.7 \mathrm{a}$ & $12.0 \mathrm{~b}$ & $10.0 \mathrm{~b}$ & 12.7 & 15.8 \\
Nonfibrous carbohydrates (NFC) & $324.0 \mathrm{c}$ & $433.9 \mathrm{a}$ & $297.9 \mathrm{c}$ & $302.6 \mathrm{c}$ & $375.8 \mathrm{~b}$ & $359.4 \mathrm{~b}$ & 33.7 & 10.7 \\
NDFap & $587.3 \mathrm{a}$ & $438.0 \mathrm{c}$ & $603.4 \mathrm{a}$ & $529.6 \mathrm{~b}$ & $492.5 \mathrm{~b}$ & $500.4 \mathrm{~b}$ & 52.9 & 7.2 \\
ADFap & $430.1 \mathrm{a}$ & $248.0 \mathrm{~d}$ & $414.3 \mathrm{a}$ & $3507 \mathrm{~b}$ & $305.9 \mathrm{c}$ & $305.1 \mathrm{c}$ & 342.3 & 7.5 \\
Lignin (LIG) & $40.9 \mathrm{~b}$ & $21.0 \mathrm{c}$ & $49.5 \mathrm{a}$ & $56.2 \mathrm{a}$ & $41.5 \mathrm{~b}$ & $50.7 \mathrm{a}$ & 43.3 & 11.7 \\
Total digestible nutrients (TDN) & $641.9 \mathrm{~b}$ & $748.8 \mathrm{a}$ & $625.6 \mathrm{c}$ & $618.4 \mathrm{c}$ & $667.8 \mathrm{~b}$ & $646.1 \mathrm{~b}$ & 658.1 & 2.9 \\
IVDMD48 (\% DM-1) & 53.2 & 78.5 & 54.5 & 56.9 & 62.4 & 65.7 & 60.7 & 0.91 \\
\hline
\end{tabular}

${ }^{(1)}$ Means followed by equal letters, in the same row, do not differ by the Scott-Knott's test, at $5 \%$ probability. NDIN/TN, neutral detergent-insoluble nitrogen in relation to total nitrogen; ADIN/TN, acid detergent-insoluble nitrogen in relation to total nitrogen; NDFap and ADFap, neutral detergent fiber and acid detergent fiber corrected for ash and protein; and IVDMD48, in vitro dry matter degradability after 48 hours of incubation. 
Sorghum 'SF 15', 'IPA 2502', 'Sudão', and 'BRS 655' showed crude protein values below $70 \mathrm{~g} \mathrm{~kg}^{-1} \mathrm{DM}$, the minimum nitrogen level for adequate ruminal fermentation. Despite the low-protein content, 'IPA 2502' had the lowest proportion of nitrogen associated to the fibrous fractions (NDIN and ADIN), which indicates that this nitrogen is more easily available for microbial metabolism during ruminal degradation. The evaluated fibrous fractions (NDFap, ADFap and Lig) were similar to those reported in the literature (Miron et al., 2007; Oliveira et al., 2009; Silva et al., 2012, 2014; Neves et al., 2015). The variation of TDN values among the cultivars may result in impaired animal performance, and may be due to differences between the proportions of the plant parts (leaves, stem and panicle) and the nutritional values of these fractions, which will interfere with the quality of the silage produced (Miron et al., 2007). The highest NFC content showed by 'IPA 2502' due to its succulent stem may be the main responsible for the highest TDN content observed.

Differences were observed in $\mathrm{pH}$, and in the acetic and propionic acid values, as well as in the ammoniacal nitrogen contents in relation to total nitrogen (Table 3). The $\mathrm{pH}$ value of the silage produced from 'BRS 655' was higher than those of the other silages. The silage from 'BRS 506' showed the highest concentration of ammoniacal nitrogen in relation to total nitrogen $\left(\mathrm{N}-\mathrm{NH}_{3} / \mathrm{TN}\right)$ and acetic acid, differing from those of the other silages. There was no difference between the lactic and butyric acid concentrations of silages ( 38.7 and $2.1 \mathrm{~g} \mathrm{~kg}^{-1} \mathrm{DM}$, respectively), but the silage from 'BRS 506' genotype had the lowest concentration of propionic acid. All tested silages showed $\mathrm{pH}$ values lower than 4.2 (Table 3), which indicates sufficient organic acid production to preserve the ensiled mass.
Considering the green forage, up to $90 \%$ of nitrogen is found in proteins, and the remaining is found mainly in the form of free amino acids and amines. Normally, less than $1 \%$ is in the form of ammoniacal nitrogen $\left(\mathrm{N}-\mathrm{NH}_{3}\right)$. Part of the nitrogen is present as low-solubility compounds, such as prolamins, or kafirins in sorghum. Because these compounds encapsulate starch granules embedded in the protein matrix, they negatively affect the total digestibility of the feed (Windle et al., 2014). During the ensiling process, by the action of endogenous plant enzymes, part of these prolamins are denatured and degraded by bacterial action, which may result in a greater availability of the starch granules to the bacterial action in the rumen. However, values above $10 \% \mathrm{~N}^{-\mathrm{NH}_{3}}$ in relation to total nitrogen indicate a high proteolytic activity and undesirable bacterial development, resulting in reduced palatability and lower intake (McDonald et al., 1991). In the present study, all silages had ammoniacal nitrogen contents below $10 \%$, which is an indicative of the control of proteolysis. Organic acids are responsible for lowering $\mathrm{pH}$ and preserving silage. Lactic acid is the one with the lowest $\mathrm{pKa}$ among the acids produced during the fermentation process. In addition, it does not result in dry matter losses as $\mathrm{CO}_{2}$ during its synthesis, and it is therefore the most desirable acid among the produced ones. Acetic acid and butyric acid are related to lower rates of $\mathrm{pH}$ decrease and to a higher-dry matter loss during the fermentation process (Muck, 2010). According to McDonald et al. (1991), the desirable values of acetic and butyric acids are below 2.5 and $0.1 \% \mathrm{DM}$, respectively. In the present study, all silages showed acetic acid concentrations below $2.5 \%$ DM, but butyric acid values were slightly above $0.1 \%$, indicating an activity of Clostridium bacteria. Nonetheless, it

Table 3. Mean values for the fermentative characteristics and concentration ( $\mathrm{g} \mathrm{kg}^{-1}$ dry matter) of the fermentation products of silages made from six sorghum (Sorghum bicolor and S. sudanense) cultivars ${ }^{(1)}$.

\begin{tabular}{|c|c|c|c|c|c|c|c|c|}
\hline Parameter & SF 15 & IPA 2502 & Sudão & BRS 655 & BRS 601 & BRS 506 & Mean & $\mathrm{CV}(\%)$ \\
\hline $\mathrm{pH}$ & $3.7 \mathrm{c}$ & $3.9 \mathrm{~b}$ & $3.9 \mathrm{~b}$ & $4.1 \mathrm{a}$ & $3.9 \mathrm{~b}$ & $3.6 \mathrm{c}$ & 3.9 & 3.6 \\
\hline $\mathrm{N}-\mathrm{NH}_{3} / \mathrm{TN}(\%)$ & $5.9 \mathrm{~b}$ & $4.4 \mathrm{~b}$ & $5.1 \mathrm{~b}$ & $5.6 \mathrm{~b}$ & $4.1 \mathrm{~b}$ & $8.2 \mathrm{a}$ & 5.6 & 26.9 \\
\hline Lactic acid (\%) & $35.8 \mathrm{a}$ & $43.3 \mathrm{a}$ & $36.1 \mathrm{a}$ & 29.1a & $38.7 \mathrm{a}$ & $41.7 \mathrm{a}$ & 37.5 & 17.8 \\
\hline Acetic acid (\%) & $7.5 \mathrm{c}$ & $11.4 \mathrm{~b}$ & $8.5 \mathrm{c}$ & $10.7 b$ & $10.3 b$ & $17.2 \mathrm{a}$ & 10.9 & 24.2 \\
\hline Propionic acid (\%) & $3.3 \mathrm{a}$ & $4.9 \mathrm{a}$ & $3.4 \mathrm{a}$ & $4.8 \mathrm{a}$ & - & $1.1 \mathrm{~b}$ & 3.5 & 25.1 \\
\hline Butyric acid (\%) & $1.6 \mathrm{a}$ & $2.6 \mathrm{a}$ & $1.4 \mathrm{a}$ & $2.9 \mathrm{a}$ & 2.1a & $2.3 \mathrm{a}$ & 2.2 & 26.4 \\
\hline
\end{tabular}

${ }^{(1)}$ Means followed by equal letters, in the same row, do not differ by the Scott-Knott's test, at $5 \%$ probability. $\mathrm{N}-\mathrm{NH}_{3} / \mathrm{TN}$, ammoniacal nitrogen in relation to total nitrogen. 
was not sufficient to raise the ammoniacal nitrogen to undesirable levels.

Sorghum 'IPA 2502' and 'BRS 506' had the highest $\mathrm{FV}_{\mathrm{NFC}}$ values and the highest $\mathrm{kd}_{\mathrm{FC}}$ (Table 4). 'IPA 2502' also showed the highest $\mathrm{kd}_{\mathrm{NFC}}$ and the lowest $\mathrm{L}$, as well as the 'BRS 655' hybrid. No differences were observed for $\mathrm{FV}_{\mathrm{FC}}$ and TV. 'IPA 2502' had the highest degradation rate of nonfibrous carbohydrates, and the highest-final gas production from this fraction. This hybrid had the highest-NFC values, the lowest-protein content and the highest-crude protein digestibility, which may be an indicative of a lower amount of kafirins associated to the starch matrix. A higherdegradation rate is desirable and may be related to a greater amount of readily fermentable substrate, such as soluble carbohydrates (Table 2).

There were no differences between the final gas volume produced from the fermentation of fibrous fractions $\left(\mathrm{FV}_{\mathrm{FC}}\right)$, but similarly to the nonfibrous carbohydrates, the fermentation rate of fibrous carbohydrates was higher for 'IPA 2502'. Lower rates of gas production from the fibrous fraction are indicative of low degradability (Silva et al., 2014). The 'IPA 2502' genotype also had the lowest-lignin content. Feeds with higher contents of soluble components and carbohydrates that are readily available to the action of microorganisms usually have smaller lag time values (Ribas et al., 2007). Despite the higher production of gases from the fibrous fractions by 'IPA 2502' and 'BRS 506', the total volume was similar between the treatments. The volume of gases produced depends on the chemical composition of the feed, mainly the contents of fibrous fractions and nonfibrous carbohydrates, as well as their total degradability. The mean total volume of gases in the present study was $194.9 \mathrm{~mL} \mathrm{~g}^{-1} \mathrm{DM}$, which is similar to those of other trials using silages from different sorghum hybrids (Mauricio et al., 2003; Silva et al., 2014). Significant differences were found for the mean dry matter disappearance among the silages evaluated (Table 4). 'IPA 2502' showed higher-DM disappearance at 4, 12,24 , and 96 hours, as well as the lowest value of nondegradable NDF I fraction among the evaluated cultivars. 'SF $15^{\prime}$ had the lowest values of DM disappearance at 4, 12, and 24 hours, and the 'BRS 655' hybrid showed the highest value of I.

Lambs fed sorghum 'IPA 2502' and 'BRS 655' showed higher consumption of dry matter (Table 5). Animals fed 'SF 15' silage consumed less dry matter and organic matter, and those that received 'Sudão' sorghum silages showed higher consumption of the fibrous fractions (NDFap and ADFap). Lambs fed 'IPA 2502', 'BRS 601', and 'BRS 506' had the highest intakes of NFC. There were no significant differences between the values of apparent digestibility of dry matter and organic matter.

Table 4. Estimates of in vitro fermentation kinetics of fibrous and nonfibrous carbohydrates, and dry matter disappearance of silages from six sorghum (Sorghum bicolor and S. sudanense) cultivars ${ }^{(1)}$.

\begin{tabular}{|c|c|c|c|c|c|c|c|c|}
\hline Parameter $^{(2)}$ & SF 15 & IPA 2502 & Sudão & BRS 655 & BRS 601 & BRS 506 & Mean & $\mathrm{CV}(\%)$ \\
\hline & \multicolumn{8}{|c|}{ Fermentation kinetics } \\
\hline 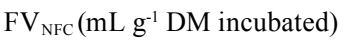 & $53.1 \mathrm{~b}$ & $94.1 \mathrm{a}$ & $49.9 b$ & $45.6 \mathrm{~b}$ & $68.2 \mathrm{~b}$ & $84.3 \mathrm{a}$ & 65.9 & 15.7 \\
\hline $\mathrm{kd}_{\mathrm{NFC}}\left(\mathrm{h}^{-1}\right)$ & $0.065 \mathrm{c}$ & $0.102 \mathrm{a}$ & $0.063 \mathrm{c}$ & $0.081 b$ & $0.079 b$ & $0.083 b$ & 0.07 & 7.5 \\
\hline Latency (hours:minutes) & $02: 42 \mathrm{a}$ & 01:06b & $01: 54 a$ & $00: 40 \mathrm{~b}$ & 02:06a & $01: 36 a$ & 01:43 & 30.2 \\
\hline $\mathrm{FV}_{\mathrm{FC}}\left(\mathrm{mL} \mathrm{g}^{-1} \mathrm{DM}\right.$ incubated $)$ & 141.0 & 132.2 & 135.9 & 120.4 & 126.6 & 117.9 & 129 & 8.8 \\
\hline $\mathrm{kd}_{\mathrm{FC}}\left(\mathrm{h}^{-1}\right)$ & $0.012 \mathrm{c}$ & $0.016 \mathrm{a}$ & $0.012 \mathrm{c}$ & $0.014 \mathrm{~b}$ & $0.014 \mathrm{~b}$ & $0.015 \mathrm{a}$ & 0.01 & 4.9 \\
\hline TV (mL g ${ }^{-1}$ DM incubated) & 194.1 & 226.3 & 185.8 & 194.8 & 166.0 & 202.2 & 194.9 & 8.8 \\
\hline Incubation time $(\mathrm{h})$ & \multicolumn{8}{|c|}{ Dry matter disappearance (\%) } \\
\hline 4 & $21.7 \mathrm{e}$ & $53.9 \mathrm{a}$ & $25.8 \mathrm{~d}$ & $32.7 \mathrm{c}$ & $32.9 \mathrm{c}$ & $39.8 \mathrm{~b}$ & 34.5 & 2.7 \\
\hline 12 & $27.5 f$ & $61.5 \mathrm{a}$ & $29.6 \mathrm{e}$ & $37.6 \mathrm{~d}$ & $40.4 \mathrm{c}$ & $45.9 \mathrm{~b}$ & 40.4 & 1.9 \\
\hline 24 & $38.5 \mathrm{~d}$ & $69.6 \mathrm{a}$ & $40.4 \mathrm{~d}$ & $45.3 \mathrm{c}$ & $52.1 \mathrm{~b}$ & $53.8 \mathrm{~b}$ & 50.0 & 3.2 \\
\hline 48 & 53.2 & 78.5 & 54.5 & 56.9 & 62.4 & 65.7 & 61.9 & 0.9 \\
\hline 96 & $58.0 \mathrm{c}$ & $76.2 \mathrm{a}$ & $59.4 \mathrm{c}$ & $60.4 \mathrm{c}$ & $64.5 \mathrm{~b}$ & $65.8 \mathrm{~b}$ & 64.1 & 2.3 \\
\hline I & $36.5 b$ & $20.3 \mathrm{e}$ & $37.2 b$ & $38.6 \mathrm{a}$ & $33.2 \mathrm{c}$ & $31.0 \mathrm{~d}$ & 32.8 & 1.6 \\
\hline
\end{tabular}

${ }^{(1)}$ Means followed by equal letters, in the same row, do not differ by the Scott-Knott's test, at $5 \%$ probability. (2) $\mathrm{FV}_{\mathrm{NFC}}$, maximum volume of gases from the fermentation of NFC; $\mathrm{kd}_{\mathrm{NFC}}$, degradation rate $\left(\mathrm{h}^{-1}\right)$ of $\mathrm{NFC} ; \mathrm{FV}_{\mathrm{FC}}$, maximum volume of gases from the FC; $\mathrm{kd}_{\mathrm{FC}}$, degradation rate $\left(\mathrm{h}^{-1}\right)$ of $\mathrm{FC} ; \mathrm{TV}$, total volume of gases from the fermentation of carbohydrates; and I, nondegradable NDF fraction. 
Table 5. Intake and apparent digestibility of dry matter and nutrients of six sorghum (Sorghum bicolor and S. sudanense) cultivars in Santa Inês sheep $(35.5 \pm 2.21 \mathrm{~kg})$ during 22 days ${ }^{(1)}$.

\begin{tabular}{|c|c|c|c|c|c|c|c|c|}
\hline Variable & SF 15 & IPA 2502 & Sudão & BRS 655 & BRS 601 & BRS 506 & Mean & $\mathrm{CV}(\%)$ \\
\hline & \multicolumn{8}{|c|}{ Intake $\left(\mathrm{g} \mathrm{DM}^{-1}\right)$} \\
\hline Dry matter (DM) & $45.65 \mathrm{c}$ & $67.07 \mathrm{ab}$ & $61.06 \mathrm{~b}$ & $74.42 \mathrm{a}$ & $64.63 b$ & $63.65 b$ & 62.74 & 9.7 \\
\hline Organic matter $(\mathrm{OM})$ & $43.75 \mathrm{c}$ & $63.02 \mathrm{ab}$ & $57.84 \mathrm{~b}$ & $68.81 \mathrm{a}$ & $61.02 \mathrm{ab}$ & $60.06 \mathrm{~b}$ & 59.08 & 9.6 \\
\hline Crude protein $(\mathrm{CP})$ & $2.16 \mathrm{e}$ & $5.37 \mathrm{~b}$ & $2.97 \mathrm{~d}$ & $6.48 \mathrm{a}$ & $5.34 \mathrm{~b}$ & $4.01 \mathrm{c}$ & 4.39 & 8.1 \\
\hline Ether extract (EE) & $0.39 \mathrm{~d}$ & $0.45 \mathrm{~d}$ & $1.48 \mathrm{c}$ & $1.89 \mathrm{a}$ & $1.67 \mathrm{a}$ & $1.33 \mathrm{c}$ & 1.20 & 9.2 \\
\hline Neutral detergent fiber (NDF) & $31.17 \mathrm{c}$ & $29.40 \mathrm{~cd}$ & $43.99 \mathrm{a}$ & $37.52 b$ & $23.95 \mathrm{e}$ & $25.41 \mathrm{de}$ & 3.91 & 11.0 \\
\hline Acid detergent fiber (ADF) & $20.81 b$ & $17.02 \mathrm{~cd}$ & $27.12 \mathrm{a}$ & $20.30 \mathrm{bc}$ & $12.63 \mathrm{e}$ & $16.31 d$ & 19.03 & 11.9 \\
\hline \multirow[t]{2}{*}{ Nonfibrous carbohydrates (NFC) } & $10.03 \mathrm{c}$ & $27.80 \mathrm{a}$ & $9.40 \mathrm{c}$ & $22.92 \mathrm{~b}$ & $30.06 \mathrm{a}$ & 29.31a & 21.59 & 9.2 \\
\hline & \multicolumn{8}{|c|}{ Apparent digestibility (\%) } \\
\hline $\mathrm{DM}$ & 0.69 & 0.68 & 0.71 & 0.65 & 0.61 & 0.66 & 0.67 & 8.4 \\
\hline $\mathrm{OM}$ & 0.72 & 0.70 & 0.73 & 0.67 & 0.64 & 0.68 & 0.69 & 7.6 \\
\hline $\mathrm{CP}$ & $0.43 \mathrm{bc}$ & $0.57 \mathrm{a}$ & $0.46 \mathrm{~b}$ & $0.45 b$ & $0.38 \mathrm{bc}$ & $0.36 \mathrm{c}$ & 0.44 & 11.7 \\
\hline $\mathrm{EE}$ & $0.49 \mathrm{~b}$ & $0.37 b$ & $0.84 \mathrm{a}$ & $0.74 \mathrm{a}$ & $0.54 \mathrm{~b}$ & $0.72 \mathrm{a}$ & 0.62 & 16.5 \\
\hline NDFap $^{(2)}$ & $0.66 \mathrm{ab}$ & $0.49 \mathrm{~cd}$ & $0.70 \mathrm{a}$ & $0.53 \mathrm{bc}$ & $0.33 \mathrm{e}$ & $0.38 \mathrm{de}$ & 0.51 & 18.0 \\
\hline $\mathrm{ADFap}^{(2)}$ & $0.66 \mathrm{a}$ & $0.47 \mathrm{~b}$ & $0.68 \mathrm{a}$ & $0.45 b$ & $0.35 \mathrm{c}$ & $0.37 \mathrm{c}$ & 0.50 & 9.5 \\
\hline NFC & $0.96 \mathrm{ab}$ & $0.96 \mathrm{ab}$ & $0.92 \mathrm{~b}$ & $0.95 b$ & $0.95 b$ & $0.99 \mathrm{a}$ & 0.95 & 2.5 \\
\hline
\end{tabular}

${ }^{(1)}$ Means followed by equal letters, in the same row, do not differ by the Scott-Knott's test, at $5 \%$ probability. NDFap and ADFap, NDF and ADF corrected for ash and protein. $\mathrm{CV}$, coefficient of variation.

The highest apparent digestibility of crude protein was obtained for lambs fed 'IPA 2502' (Table 5).

The highest digestibility of fibrous fractions (NDFap and ADFap) were obtained for 'SF 15' and 'Sudão', and the lowest one for 'BRS 601' and 'BRS 506'. All cultivars had high digestibility of nonfibrous carbohydrates. Silage of 'BRS 506' had higher digestibility compared to 'Sudão', 'BRS 655', and 'BRS 601'. Different aspects may influence the digestibility of feed, such as chemical composition, adhesion capability, and action of bacterial enzymes on its surface, besides the absence of compounds potentially toxic to microorganisms. Higher values of potentially indigestible compounds, such as lignocellulose, can slow the rate of passage and restrict intake, resulting in loss of performance (Krizsan et al., 2010). On the other hand, a higher initial degradability, combined with the lower-lag time, may be responsible for the higher intake in sheep fed 'IPA 2502' silage.

Lambs fed silage from 'SF 15' showed the lowest values of nutrient consumption among the evaluated silages. Probably, low levels of crude protein and nonfibrous carbohydrates resulted in slower ruminal metabolism due to the lack of readily available substrate for ruminal bacteria. This fact was evidenced by the lower-degradation rates of both nonfibrous carbohydrates and fibrous carbohydrates and by the lag time, resulting in lower-dry matter degradation, even after 96 hours of incubation.

The apparent digestibility of dry matter and that of organic matter were not affected by the tested cultivars, differently from what was observed during the in vitro experiment. The apparent digestibility values in the present study were similar to those found in the literature, both in tropical and temperate conditions (Miron et al., 2007; Machado et al., 2015).

\section{Conclusions}

1. The silage from sorghum 'IPA 2502' has the lowest contents of moisture, neutral detergent fiber, and acid detergent fiber, the highest ones of nonfibrous carbohydrates and total digestible nutrients, and the greatest dry matter degradability.

2. Lambs feeding on silage from 'IPA 2502' consume more dry matter and nonfibrous carbohydrates; in addition, the crude protein digestibility is higher in these animals.

3. Silages from 'BR 601' and 'BRS 506' have the highest crude protein levels, whereas those from 'SF 15' and 'Sudão' have the highest contents of fibrous fractions. 
4. The mean total volume of gases produced do not vary among the evaluated cultivars.

\section{Acknowledgments}

To Conselho Nacional de Desenvolvimento Científico e Tecnológico (CNPq) / Fundo Setorial do Agronegócio (CTAgro), to Coordenação de Aperfeiçoamento de Pessoal de Nível Superior (Capes) / Programa Professor Visitante do Exterior (PVE), to Empresa Brasileira de Pesquisa Agropecuária (Embrapa), to Fundação de Amparo à Pesquisa do Estado de Minas Gerais (Fapemig), and to Banco do Nordeste, for support.

\section{References}

ADAMS, R.F.; JONES, R.L.; CONWAY, P.L. High-performance liquid-chromatography of microbial-acid metabolites. Journal of Chromatography B: Biomedical Sciences and Applications, v.336, p.125-137, 1984. DOI: 10.1016/S0378-4347(00)85136-1.

BRÜNING, D.; GERLACH, K.; WEIß, K.; SÜDEKUM, K.H. Effect of compaction, delayed sealing and aerobic exposure on maize silage quality and on formation of volatile organic compounds. Grass and Forage Science, v.73, p.53-66, 2018. DOI: 10.1111/gfs.12288.

COSTA, R.F.; PIRES, D.A. de A.; MOURA, M.M.A.; RODRIGUES, J.A.S.; ROCHA JÚNIOR, V.R.; TOLENTINO, D.C. In situ degradability of dry matter and fibrous fraction of sorghum silage. Acta Scientiarum. Animal Sciences, v.38, p.171176, 2016.

DETMAN, E.; VALADARES FILHO, S. de C.; HENRIQUES, L.T.; PINA, D. dos S.; PAULINO, M.F.; MAGALHÃES, A.L.R.; FIGUEIREDO, D.M. de; PORTO, M. de O.; CHIZZOTTI, M.L. Reparametrização do modelo baseado na lei de superfície para predição da fração digestível da fibra em detergente neutro em condições brasileiras. Revista Brasileira de Zootecnia, v.36, p.155-164, 2007. DOI: 10.1590/S1516-35982007000100019.

HELRICH, K. (Ed.). Official methods of analysis of the AOAC. $15^{\text {th }}$ ed. Arlington: Association of Official Analytical Chemists, 1990. $1117 \mathrm{p}$.

KRIZSAN, S.J.; AHVENJARVI, S.; HUHTANEN, P. A metaanalysis of passage rate estimated by rumen evacuation with cattle and evaluation of passage rate prediction models. Journal of Dairy Scince, v.93, p.5890-5901, 2010. DOI: 10.3168/jds.20103457.

LEDGERWOOD, D.N.; DEPETERS, E.J.; ROBINSON, P.H.; TAYLOR, S.J.; HEGUY, J.M. Assessment of a brown midrib (BMR) mutant gene on the nutritive value of sudangrass using in vitro and in vivo techniques. Animal Feed Science and Technology, v.150, p.207-222, 2009. DOI: 10.1016/j. anifeedsci.2008.10.001.
MACHADO, F.S.; RODRÍGUEZ, N.M.; GONÇALVES, L.C.; RODRIGUES, J.A.S.; RIBAS, M.N.; PÔSSAS, F.P.; JAYME, D.G.; PEREIRA, L.G.R.; CHAVES, A.V.; TOMICH, T.R. Energy partitioning and methane emission by sheep fed sorghum silages at different maturation stages. Arquivo Brasileiro de Medicina Veterinária e Zootecnia, v.67, p.790-800, 2015. DOI: 10.1590/1678-4162-7177.

MAURÍCIO, R.M.; PEREIRA, L.G.R.; GONÇALVES, L.C.; RODRIGUEZ, N.M. Relação entre pressão e volume para a implantação da técnica in vitro semi-automática de produção de gases na avaliação de forrageiras tropicais. Arquivo Brasileiro de Medicina Veterinária e Zootecnia, v.55, p.216-219, 2003. DOI: 10.1590/S0102-09352003000200014.

MCDOnAld, P.; HENDERSON, A.R.; HERON, S.J.E. The biochemistry of silage. $2^{\text {nd }}$ ed. Marlow: Chalcombe, 1991. 340p.

MENKE, K.H.; STEINGASS, H. Estimation of the energetic feed value obtained from chemical analysis and gas production using rumen fluid. Animal Research and Development, v.28, p.7-55, 1988.

MERTENS, D.R. Gravimetric determination of amylase-treated neutral detergent fiber in feeds with refluxing in beakers or crucibles: collaborative study. Journal of AOAC International, v.85, p.1217-1240, 2002.

MIRON, J.; ZUCKERMAN, E.; ADIN, G.; NIKBACHAT, M.; YOSEF, E.; ZENOU, A.; WEINBERG, Z.G.; SOLOMON, R.; BEN-GHEDALIA, D. Field yield, ensiling properties and digestibility by sheep of silages from two forage sorghum varieties. Animal Feed Science and Technology, v.136, p.203215, 2007. DOI: 10.1016/j.anifeedsci.2006.09.001.

MOURA, M.M.A.; PIRES, D.A. de A.; RODRIGUES, J.A.S.; SALES, E.C.J. de; COSTA, R.F.; TOLENTINO, D.C.. Chemical composition of sorghum genotypes silages. Acta Scientiarum. Animal Sciences, v.38, p.369-373, 2016. DOI: 10.4025/ actascianimsci.v38i4.31810.

MUCK, R.E. Silage microbiology and its control through additives. Revista Brasileira de Zootecnia, v.39, p.183-191, 2010. Suplemento especial. DOI: 10.1590/S1516-35982010001300021.

NEVES, A.L.A.; SANTOS, R.D. dos; PEREIRA, L.G.R.; TABOSA, J.N.; ALMEIDA, M.R.M. de; ALMEIDA, M.R.M. de; RODRIGUES, J.A dos S.; NEVES, A.L.A.; VERNEQUE, R. da S. Agronomic characteristics of sorghum cultivars for silage production in the Agreste of Pernambuco state. Revista Brasileira de Milho e Sorgo, v.13, p.382-390, 2014. DOI: 10.18512/19806477/rbms.v13n3p382-390.

NEVES, A.L.A.; SANTOS, R.D.; PEREIRA, L.G.R.; OLIVEIRA, G.F.; SCHERER, C.B.; VERNEQUE, R.S.; MCALLISTER, T. Agronomic characteristics, silage quality, intake and digestibility of five new Brazilian sorghum cultivars. Journal of Agricultural Science, v.153, p.371-380, 2015. DOI: 10.1017/S002185961400063X.

OLIVEIRA， S.G. de; BERCHIELLI, T.T.; REIS, R.A.; VECHETINI, M.E.; PEDREIRA, M. dos S. Fermentative characteristics and aerobic stability of sorghum silages containing different tannin levels. Animal Feed Science and Technology, v.154, p.1-8, 2009.

Pesq. agropec. bras., Brasília, v.53, n.2, p.256-264, Feb. 2018 DOI: $10.1590 / \mathrm{S} 0100-204 \mathrm{X} 2018000200015$ 
RIBAS, M.N.; GONÇALVES, L.C.; MAURÍCIO, R.M. Degradabilidade e cinética de fermentação ruminal das silagens de quatro híbridos de milho, avaliadas pela técnica in vitro semiautomática de produção de gases. Revista Brasileira de Milho e Sorgo, v.6, p.223-233, 2007. DOI: 10.18512/1980-6477/rbms. v6n2p223-233.

SANTOS, R.D. dos; PEREIRA, L.G.R.; NEVES, A.L.A.; RODRIGUES, J.A.S.; COSTA, C.T.F.; OLIVEIRA, G.F. de. Agronomic characteristics of forage sorghum cultivars for silage production in the lower middle San Francisco Valley. Acta Scientiarum. Animal Sciences, v.35, p.13-19, 2013.

SCHOFIELD, P.; PITT, R.E.; PELL, A.N. Kinetics of fiber digestion from in vitro gas production. Journal of Animal Science, v.72, p.2980-2991, 1994. DOI: 10.2527/1994.72112980x.

SILVA, T.C. da; SANTOS, E.M.; MACEDO, C.H.O.; LIMA, M.A. de; BEZERRA, H.F.C.; AZEVÊDO, J.A.G.; RODRIGUES, J.A.S.; OLIVEIRA, J.S. de. Divergence of the fermentative and bromatological characteristics of 25 sorghum hybrid silages. Revista Brasileira de Zootecnia, v.41, p.1127-1133, 2012. DOI: 10.1590/S1516-35982012000500007.

SILVA, T.C.; SANTOS, E.M.; MACEDO, C.H.O.; LIMA, M.A.; AZEVEDO, J.A.G.; PINHO, R.M.A.; PERAZZO, A.F.;
OLIVEIRA, J.S. Cinética de fermentação ruminal in vitro de silagens de híbridos de sorgo. Arquivo Brasileiro de Medicina Veterinária e Zootecnia, v.66, p.1865-1873, 2014. DOI: 10.1590/1678-6221.

THEODOROU, M.K.; WILLIAMS, B.A.; DHANOA, M.S.; MCALLAN, A.B.; FRANCE, J. A simple gas production method using a pressure transducer to determine the fermentation kinetics of ruminant feeds. Animal Feed Science and Technology, v.48, p.185-197, 1994. DOI: 10.1016/0377-8401(94)90171-6.

VAN SOEST, P.J.; ROBERTSON, J.B. Analysis of forages and fibrous foods. Ithaca: Cornell University, 1985. 202p.

WHEELER, T.; VON BRAUN, J. Climate change impacts on global food security. Science, v.341, p.508-513, 2013. DOI: 10.1126/science.1239402.

WINDLE, M.C.; WALKER, N.; KUNG JR, L. Effects of an exogenous protease on the fermentation and nutritive value of corn silage harvested at different dry matter contents and ensiled for various lengths of time. Journal of Dairy Science, v.97, p.3053-3060, 2014. DOI: 10.3168/jds.2013-7586.

Received on September 22, 2016 and accepted on June 2, 2017 